\title{
PROBLEMS OF SHOW CAVES IN BOHEMIA AND MORAVIA
}

\author{
Milka Dusan*
}

\section{SUMMARY.}

In the last years the show caves in Bohemia and Moravia were administrated by the Ministry of Culture with the status of a state assisted organization. That means that they were considered as those organizations not self-sufficient, without connections with tourism.

Presently, the management of the show caves in Bohemia and Moravia is at a crossroad: to remain under the administration of the Ministry of Culture or move under the newly formed Ministry of Environment. In the latter case the cave management should change into a business organization similar to a private body.

We believe that these problems can be fairly solved by the newly formed National Show Caves Association.

\section{ZUSAMMENFASSUNG [Probleme des Schauhöhlen in Böhmen und Mähren]}

In den vergangenen Jahren wurden die Schauhöhlen in Böhmen und Măhren durch das Kulturministerium verwaltet, wobei diese als "zuschussgetragene" (d.h. staatlich geförderte) Organisationen eingerichtet wurden. Des halb wurden sie als okonomisch selbstragend betrachtet und als solche von weiteren Bindungen, etwa an den Reisebetrieb abgeschnitten.

Gegenwärtig befinden sich die Verwaltungen der Schauhöhlen in Böhmen und Mähren an einem Scheideweg: Es handelt sich um die Frage, ob es weiterhin staatlich geförderte Organisationen bleiben oder ob es selbständige Unternehmen werden sollen; ob die zentral dirigierten Verwaltungen der Schauhölen weiterbestehen ob sie als Bestandteile der auf den Reisebetrieb orientierten Aktiengesellschaften oder als privatisierte Betriebe weiterexistieren sollen.

Wir möchten glauben, dass diese Probleme seitens der neuentstehenden Landesorganisation der Schauhöhlen gelöst werden.

In the middle of the Fifties the central authority moved also in the field of show caves management. At the time, show caves were operated by private persons or by cooperatives, nearly as in other countries.

In Moravian Karst, the most known area in Czech Republic, the show caves Punkevní, Katerinská, Balcarka and Sloupské were operated by the association "Turista". They were managed according to economic criteria in order to be self-sustaining, of course in connection with other tourist activities. E.g. the association "Turista" operated also some regular bus connection from the town of Blansko to the centre of Moravian Karst.

Other caves were private property: Chynov cave in the southern Bohemia was the property of the Rothbauer family. Thanks to a sensitive management and notwithstanding the lack of speleothems, it was regularly

\footnotetext{
* 512 13; Bozkov 253 (Slovakia)
} 
visited by tourists

In 1956, af Nature Protection Act was passed in Bohemia and Moravia. According to this Act, show caves were declared protected natural objects and in the frame of the last wave of nationaliziation, they were transferred under the Ministry of Culture.

I agree that caves are part of the National Cultural Heritage and that show caves may be linked to other cultural activities. But the intentions of our central authorities were moved by a political view and slowly show caves became pure "containers" of cultural events sometimes without any connection with the cave itself.

According to these criteria show caves were evaluated, e.g., according to the number of lectures or the number of exhibitions installed every year. Concerts were also organized in show caves and musical festivals were common especially in Moravian Karst. In another case a cave wase transformed into a theatre; a show cave in the northern Moravia was used as an exhibition for a sculptor and the tourist payed not only for visiting the cave but also for visiting the exhibition.

The original idea to give to artists and to visitors unusual and unique atmospheres became the leading criterion for the managers of show caves. When advertising was reduced because the state had to save money, in some caves the salaries of staff depended on the number of visitors, that means on tickets sold. In Bozkov Dolomite Caves it took a lot of time to persuade our boss that it is not possible to use the number of tourists as the unique index of activity and, what is the worst, to plan a growing number of visitors every year.

Who knows our small caves with narrow passages, he can imagine that in the full season, in the years 1986-1989, we were not able to increase the number of visitors simply because of the lack of space. On the other hand services connected with show caves like refreshment, accommodation, snaps photo, etc.. were cancelled or transferred to other organizations. Reason? Coffee or hot dogs have nothing to share with culture! In show caves, only souvenirs with a given cultural level controlled by a central authority can be sold.

My personal opinion is that managers of show caves should try to keep a certain equilibrium between the number of visitors and the protection of the cave environment. But when the national economy is depresses, when the tourists industry is not developed, when advertising is reduced, the managers of the show caves are not able to influence the changes of the number of visitors.

Concerning the protection of caves, which was organized by the Ministry of Culture, let me emphasize some main points. I do not think that there is any cave in my country where the protection is to be put in the first place, e.g. like in Bear cave in Poland. For our show caves, the tourists who came after a whole-year-hard-work to have leisure and to see caves had the highest priority.

I do not mean that our caves were left in the hands of the visitors because the show caves managers did their best to preserve the treasure of their speleothems. Nevertheless many of these speleothems were destroyed. 
In the high season many show caves were overcrowded mainly by large groups of organized tours and the maximum number of visitors was exceeded.

A certain amount of damaged speleothems was the obvious consequence. The managers interested in the protection of caves were stressed but they were also sometime responsible because of the low standard of the protection actions.

In late eighties the problem reached its maximum because there was not enough money from Ministry of Culture for further development of caves, particularly for investments. In that period the number of tourists increased of about 25 to $30 \%$ with reference to previous years. The general situation worstened and the protection of caves was jeopardized. Many managers developed secondary protection systems to counterbalance the growing number of tourists in caves. Sometimes the visit conditions in caves were changed; e.g., the guide stopped to give explanations in such places only where he could see all tourists or a second guide was placed at the end of the group. In some parts of the caves, technical protective measures, like nets, were used.

Concerning to the relation between protection and budget. my opinion is that any economic pressures on caves may result in a danger for it independently if the cave belongs to the state or to a private. But my feeling is that the economic pressure may be higher for private caves.

A positive role was played by the state during the opening of caves for tourists because it costs a large amount of money. I want to call your attention on the example of the Bozkov Dolomite cave, the youngest show cave in Czech and Slovak Federative Republic. The setting of these show caves was better than in many other caves abroad and I can hardly imagine a private person investing so much money in such an endeavour.

Presently the main problem, after the conditions of our republic changed radically, is the question to know in which direction the development will move and who will be the owner of the show caves. All present cave managers are against privatization because they fear an increased devastation of the cave environment.

The fact is that middle and younger generations have no business experience and most of the caves have no clear development plans. In particular some buildings are obsolete and rather few caves only are selfsustaining: most of show caves need additional contributions. In the present condition of economic stress with the transition to a capitalistic economy in C.S.F.R., also the cave management has to adapt to the new situation.

Therefore cave managers tryed to organize their association at the beginning of 1990 . They tryed to find funds for the associaton in order to support caves budget. Initially this association should receive additional support, as grants from the state, and distribute it to individual caves. Then these grants should be gradually lowered until the show caves could be completely self-sustaining.

We would like to follow the examples of other associations. Thanks to Mr. Russel H. Gurnee we could get the know-how from the American National Association. Obviously the situation and the conditions in tourist industry in 
Czech and Slovak Federative Republic and in the USA are completely different and the know-how cannot be trasferred without any change and we should find out our own way.

In past years, many speleologists travelled abroad but unfortunately cave managers did not. Now, after the so called "Velvet Revolution" our boundaries are open and we would like to exchange information on show caves management abroad.

I hope that our show caves association in the frame of I.S.C.A. will contribute to the solution of this problem. In the Czech and Slovak Federative Republic there are nice, interesting and, in some case, unique show caves deserving much attention.

In the present time the Ministry of Environment in Czech Republic is willing to co-ordinate all show caves and organize a unified management of the exsisting 12 show caves. The protection of caves should be emphasized and the economic base should be formed by grants. Time will show if it is the best solution to the problems of show caves in Bohemia and Moravia. 